\title{
Seabed image acquisition and survey design for cold water coral mound characterisation
}

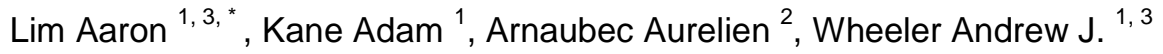

${ }^{1}$ School of Biological, Earth and Environmental Sciences, University College Cork, Distillery Fields, North Mall, Cork, Ireland

${ }^{2}$ Unité Systèmes sous-Marins, Centre de Méditerranée, Ifremer, Zone Portuaire de Brégaillon, CS 20330, 83507 La Seyne/Mer Cedex, France

${ }^{3}$ Irish Centre for Research in Applied Geosciences, University College Cork, Ireland

* Corresponding author : Aaron Lim, email address : aaron.lim@ucc.ie

\begin{abstract}
:
Cold-water coral (CWC) habitats are commonly regarded as hotspots of biodiversity in the deep-sea. However, a standardised approach to monitoring the effects of climate change, anthropogenic impact and natural variability through video-surveying on these habitats is poorly-established. This study is the first attempt at standardising a cost-effective video-survey design specific to small CWC mounds in order to accurately determine the proportion of facies across their surface. The Piddington Mound of the Moira Mounds, Porcupine Seabight, offshore Ireland has been entirely imaged by downward-facing video in 2011 and 2015. The 2011 video data is navigated into a full-mound, georeferenced video mosaic. A quadrat-based manual classification of this video mosaic at $0.25 \mathrm{~m} 2$ resolution shows the exact proportion of facies abundance across the mound surface. The minimum number of random downward-facing images from the mound are determined to accurately characterise mound surface facies proportions. This minimum sample size is used to test the effectiveness of various common survey designs for ROV-video-based habitat investigations. Single-pass video lines are not representative of the mound surface whilst gridded survey designs yield best results, similar to $100 \%$ mound coverage. The minimum sample size and manual classification are applied to the 2015 video data to show a $19 \%$ mound surface facies change over 4 years at $0.25 \mathrm{~m} 2$ resolution. The proportion of live coral facies show little change while coral rubble facies show most change. This highlights an inconsistency between temporally-separated data sets and implies that in 20 years, the mound surface may almost entirely change.
\end{abstract}




\section{Highlights}

- We utilise novel video mosaic mapping to determine the minimum number of images required to acccuratley characterise a coral mound. We assess various video survey designs to determine which produces the most mound surface representative results. The most representative survey design and number of images are re-applied 4 years later to assess the rate of change at $25 \mathrm{~cm}$ resolution. We show that over 4 years, assuming a linear rate of change, approx. $20 \%$ of the mound surface has changed.

Keywords : Cold water corals, Mounds, Video survey design, Sediments, Habitat mapping 


\section{$31 \quad 1 \quad$ Introduction}

32 Cold-water corals (CWC) are sessile, filter-feeding organisms found in many parts of the

33 world's oceans, being common and well-studied in the NE Atlantic (Freiwald, 2002; Roberts

34 et al., 2003; Roberts et al., 2006; Wheeler et al., 2007). Also referred to as "deep-water" corals,

35 their distribution actually covers a large depth range being found from $39 \mathrm{~m}$ to $2000 \mathrm{~m}$ water

36 depth (Freiwald et al., 2004; Roberts et al., 2006). As their name suggests, they typically exist

37 in cooler waters from $4^{\circ} \mathrm{C}$ to $13^{\circ} \mathrm{C}$ (Freiwald, 2002) with the exception of Oculina spp., and

38 within a salinity range of $31.7 \%-38.8 \%$ (Davies et al., 2008). Lophelia pertusa is the most

39 well-studied framework-forming CWC and is reliant on currents for food supply (Orejas et al.,

40 2016; Purser et al., 2010 and references therein) and can form 3D carbonate structures that

41 benefit from its ability to baffle currents and thereby enhance sedimentation (Wheeler,

42 Kozachenko, et al., 2005; Wheeler et al., 2008). The complex hydrodynamic relationship

43 between the CWC framework, food supply, currents and sedimentation often results in the

44 generation of positive bathymetric features on the seabed called CWC mounds (De Mol et al.,

45 2007; Dorschel, 2003; Squires, 1964; Wilson, 1979). Wilson (1979) and Squires (1964)

46 describe the early-stage development of cold-water coral mounds using evidence from rock

47 outcrop, museum specimens and submersible dives. Through successive and continuous 
periods of CWC mound development in the same location, they can generate bathymetric features up to $350 \mathrm{~m}$ from base to summit (Henriet et al., 2014 and references therein). Evidence from a number of studies show that the continued development of these coral mounds is largely controlled by environmental conditions (Dullo et al., 2008; Raddatz et al., 2014; Rüggeberg et al., 2007), sediment supply (De Mol et al., 2007; Wheeler, Kozachenko, et al., 2005) and biological processes (Wienberg et al., 2008). Furthermore, a number of mounddevelopment models linked to glacial-interglacial cycles have been presented (Douarin et al., 2014; Eisele et al., 2008; Roberts et al., 2009; Wheeler and Stadnitskaia, 2011).

Advances in marine survey technologies and techniques have fostered novel research opportunities to help better understand the marine environment, particularly in cold-water coral habitats (e.g. Freiwald and Wilson, 1998; Mangini et al., 1998; Mortensen et al., 2001; Roberts et al., 2009). As such, marine remotely-sensed mapping of CWC habitats is becoming 60 progressively more common through the use of side scan sonar (SSS) and multibeam echosounders (MBES). For example, Huvenne et al. (2005) examine the influence of currents and sediment dynamics on the growth of coral and mound development at a mound province scale whereas Dorschel et al. (2009) provide an environmental context to cold-water coral carbonate mound development, both using regional SSS mapping (TOBI $30 \mathrm{kHz}$ SSS). More recently, increased resolution $(0.2 \mathrm{~m} \times 0.2 \mathrm{~m})$ SSS surveying has allowed for detailed inspections of coral habitat change in Marine Protected Area's over relatively short timescales (Huvenne et al., 2016). MBES has also proven an integral part of marine habitat mapping for CWC habitats using hull-mounted (Beyer et al., 2003), ROV-mounted (Dolan et al., 2008; Lim et al., 2017), AUV-mounted (Correa et al., 2012) and forward-facing MBES systems (Huvenne et al., 2011). With recent advances in more accurate underwater positioning for deployed marine sampling/surveying equipment (Chitre et al., 2008; Kinsey et al., 2006), ground-truthing of 
marine remotely-sensed mapping coverages is now possible with the effective positioning of

74

still camera and video (ROV and drop frame). ROV video has proven useful in both covering large areas (Guinan et al., 2009; Huvenne et al., 2005) and providing baseline studies (Vertino et al., 2010) within CWC habitats. More recently, techniques for imaging complex structures in difficult, deep-water environments has become better developed at higher resolutions (e.g. Robert et al., 2017).

Temporal variability across CWC habitats has been studied at various scales. Lavaleye et al. (2009) utilize long time-series datasets to understand CWC habitat functioning and its effect on the organic biochemistry of the mound-influencing water column. Anthropogenic impact (trawling activities and drill cutting) at CWC habitats have driven some temporal variability research. However, these studies reveal information about temporal mound surface change utilising different approaches to video inspection at 1, 4 or 10 year timescales (Huvenne et al., 2016; Lundälv et al., 2008; Purser, 2015).

It is now more common to map (bathymetry and backscatter), physically sample (coring and grabs) and image (ROV video) CWC habitats for research purposes. Various combinations of these data types at differing resolutions in different geographic settings, and quite often with a temporal gap between sampling, are utilised to make parallels and contrasts between these habitats. Although not ideal, this is often done due to the costly and time-consuming nature of deep-water data acquisition under weather- and sea state-dependant conditions. However, a common finding of this research is the heterogeneity of these habitats (Lim et al., 2017; Vertino et al., 2010; Wienberg et al., 2009) stressing the need for local-scale studies (Davies and Guinotte, 2011; Dolan et al., 2008; Robert et al., 2016) with a robust sampling density. In light of this, our aim is to identify the minimum amount of imagery needed to accurately quantify the proportion of sediment facies on surface of an individual CWC mound and assess how to best collect this imagery in a representative manner. Furthermore, CWC mounds exist in 
dynamic environments but how rapidly do these mounds change? Growth rates of corals give us a clue but how does that translate into full-mound surface change? This study therefore also assesses relative temporal change in mound surface facies and uses this data to assess the temporal consistency of data. However, this method should be corroborated in other areas to assess its robustness.

\section{Materials and Methods}

\subsection{Study Site}

The Piddington Mound, a CWC mound in the Belgica Mound Province (BMP), has been selected for this study due to the existence of high-resolution imagery (Video and bathymetry) with sufficient spatial mound coverage as presented in Lim et al. (2017). The BMP is located on the eastern slope of the Porcupine Seabight, NE Atlantic (Fig. 1). Previously designated as a Special Area of Conservation (SAC) under the EU Habitats Directive, the BMP hosts 2 chains of contour-parallel giant CWC carbonate mounds ranging in height from $50 \mathrm{~m}$ to $100 \mathrm{~m}$ and having a slight elongate to conical morphology (Wheeler, Kozachenko, et al., 2005). A salinity maximum from $600 \mathrm{~m}$ to $1000 \mathrm{~m}$ water depth marks the depth range of the Mediterranean Outflow Water (MOW), the main mound-influencing water mass in the BMP where intermediate nepheloid layers increase food availability and lateral transport of coral larvae and therefore, influencing their distribution (Dullo et al., 2008; White, 2007).

Between and around these chains of giant CWC carbonate mounds, are approximately 250 CWC mounds, referred to as the "Moira Mounds" (Wheeler et al., 2011) of which the Piddington Mound is an example. They are small (typically $\sim 10 \mathrm{~m}$ tall and $40 \mathrm{~m}$ x $60 \mathrm{~m}$ in areal extent) with an ovoid to elongate morphology. It is speculated that they are Holocene in age (Huvenne et al., 2005). They exist in various different settings: at the head of sediment wave trains, within a blind channel, around barchan sediment waves or on gravel ridges and 
122 occur as isolated or, more commonly, clustered examples (Wheeler, Beck, et al., 2005). They

123 can be divided into 4 different areas based on their geographic distribution: the upslope area,

124 the northern area, the downslope area and the midslope area. The Moira Mounds within the

125 downslope area, where the Piddington Mound resides, are concentrated within part of the

126 Arwen Channel (Murphy and Wheeler, 2017; Van Rooij, 2004). This area has been described

127 as favourable for CWC mound development with current speeds of approximately $40 \mathrm{~cm} \mathrm{~s}^{-1}$

128 (Lim, 2017). The surrounding seabed is dominated by dropstones while the Piddington Mound

129 itself is dominated by Lophelia pertusa and Madrepora oculata colonies. It has four distinct

130 facies (live coral framework, dead coral framework, coral rubble and hemipelagic sediment

131 with dropstones) occurring in a ring-like distribution around the mound summit (Lim et al., 132 2017).

<Insert Figure 1>

\subsection{Video data}

136 Two ROV-video datasets were collected for this research. The first video dataset (referred to

137 from here on as “T1") was collected during the VENTuRE survey (2011) on board RV Celtic

138 Explorer with the Holland 1 ROV (cruise number CE11009: Wheeler and shipboard party,

139 2011). The second video dataset (referred to from here on as "T4") was collected during the

140 QuERCi survey (2015) on board RV Celtic Explorer with the Holland 1 ROV (cruise number

141 CE15009: Wheeler and shipboard party, 2015). Both research cruises collected video data over

142 the Piddington Mound using a downward-facing HD camera mounted on the bottom of the

143 ROV. Positioning and navigation for the ROV during dives were achieved using a Sonardyne

144 Ranger 2 USBL (ultra-short baseline positioning system) corrected by RDI Workhouse doppler

145 velocity logger. The ROV altimeter recorded and logged the height of the ROV (and therefore

146 camera) above the seabed. The ROV recorded downward-facing HD video during a series of 
147 transects covering the entire surface of the Piddington Mound. To maintain a clear image of

148 the mound surface, the ROV was flown $<2 \mathrm{~m}$ above the mound surface at a survey speed of $<2$

149 knots. Several lights were attached to the ROV to achieve homogenous lighting across the

150 camera field of view.

151 The T1 ROV-video dataset was converted into a video mosaic (Lim, 2017; Lim et al., 2017)

152 using the IFREMER in-house software Matisse where the images were extracted from the raw

153 video data at a rate of 1 per second. Poor quality video data (from imagery flown at over $2 \mathrm{~m}$

154 above the seabed, or collected in poor water quality or with poor navigation) were excluded

155 from the image extraction process. To lower ROV trajectory noise, all the USBL navigation

156 data were filtered using a sliding median filtering and 2 nd order polynomial model fit. The

157 extracted images and filtered navigation were then synced so each image had an approximate

158 position, which is later refined by the mosaicking process. At this point, features in the

159 extracted images were both detected and matched using a SIFT (Scale Invariant Feature

160 Transform) Algorithm (Lowe, 1999). Image matching and USBL navigation were merged to

161 give an accurate global position, correct scaling and sufficient local overlapping through a cost

162 function minimisation. This method is similar to Ferrer et al. (2007) except cost function

163 weights are affected according to image and navigation data standard deviations so re-

164 projection errors are minimized in the mosaicking plane rather than the image plane. After the

165 image positions are refined, the mosaic can be drawn incorporating seaming and blending

166 techniques developed by Burt and Adelson (1983) and Kwatra et al. (2003). The resulting video

167 mosaic is shown in Figure 2.

<Insert Figure 2> 
169 The georeferenced T1 video mosaic was imported to ArcMap where a fishnet made up of 0.25

$170 \mathrm{~m}^{2}$ cells was overlaid on the Piddington Mound mosaic. A manual classification was carried

171 out on the mosaic using the following classifiers: "hemipelagic sediment with dropstones",

172 "coral rubble", "hemipelagic sediment", "dead coral framework" and "live coral framework"

173 (see Fig. 2). The classified fishnet was saved as a shapefile and plotted in ArcMap (Fig. 3).

\section{<Insert Figure $3>$}

\section{$175 \quad 2.3 \quad$ Image sampling analysis}

176 To determine the minimum amount of imagery (photographic or still-video) needed from the

177 Piddington Mound to accurately characterise the diversity of surface facies present, sample size estimation (specific to multinomial proportions) was carried out according to Thompson (1987). While other sample size estimation techniques exist (e.g. Angers, 1974), this particular

180 technique is chosen for its robustness and accuracy even in worst case scenarios i.e. when the

181 population proportions (in this case facies proportions) are all equal. The classified cells from the Piddington Mound describe a multinomial distribution with 6 different classes: "hemipelagic sediment with dropstones", “coral rubble", "hemipelagic sediment”, "dead coral framework", "live coral framework" and "no data" (where there is a data gap as a result of data quality being too low to mosaic). To do this, the confidence interval accuracy was defined by selecting an alpha level $(\alpha)$, which represents the significance level at which the confidence

187 level is calculated (e.g. an alpha level of 0.05 gives a confidence level of $95 \%$ ) and margin of error (d). This ensured the probability that population proportions (facies proportions) across the whole mound surface were covered by the confidence interval. Thompson (1987) provides

190 a table showing the minimum sample size required once these values are defined (see Table 1).

191 For this study, a confidence interval of $95 \%$ was defined (i.e. $\alpha$ of 0.05 ) with a margin of error 
192 (d) of 0.05 allowing a sample size, $X$ ( $\mathrm{n}$ if $\mathrm{d}=0.05$ ), to be determined (see Table 1 ). Note, both

193

194

195 smaller values of $\alpha$ and smaller margins of error (d) would require larger sample sizes $(X)$ and this method does not take into account spatial autocorrelation. This does not appear to be an issue as all results occur within the $95 \%$ confidence interval regardless.

\section{$\langle$ Insert Table 1>}

196 To determine the best method for collecting images of the mound surface to most effectively

197 capture mound heterogeneity, a series of potential survey designs were performed for the

198 Piddington Mound in ArcMap and saved as *.shp files (Fig. 4). These are used as a guide for

199 a hypothetical drop camera system or ROV to acquire downward-facing stills or live video

200 from which stills can be extracted. The survey designs include the following: a) SD1 - random points; b) SD2 - south to north transect; c) SD3 - east to west transect; d) SD4 - northwestsoutheast diagonal transect; e) SD5 - 2 lines; f) SD6 - 3 straight, parallel line grid; g) SD7 - 3 summit-crossing lines; h) SD8 - horizontal grid; i) SD6 - spiral (circling from the mound base to the mound summit) and; j) SD7 - actual survey example (taken from ROV reconnaissance dive navigation over the Piddington Mound). Using the "create random points" tool in ArcMap, $X$ number of random points were generated across the surface of the Piddington Mound (SD1). To collect random points from anywhere on the mound surface, the full mound surface must therefore be imaged thus, SD1 represents the scenario of having full-mound video mosaic coverage. Then, to represent each of the other scenarios, $X$ number of random points were generated across the fishnet but restricted to the lines defining each survey design *.shp file

211 (SD2 to SD10: Figure 4). The proportion of cells of each class for each survey design was

212 calculated. The total number of $0.25 \mathrm{~m}^{2}$ cells in the fishnet from each class were also counted 213 and the proportion of these cells calculated. This acts as the real-life control against which 
214 results from each survey design can be compared. The results were graphed and the number of

215 "no data" values recorded within each survey design are used to generate proportional error 216 bars for each individual class.

\section{<Insert Figure 4>}

$218 \quad 2.4 \quad$ Temporal variability analysis

219 A repeat survey of the Piddington Mound was undertaken four years after T1 and termed T4.

220 The T4 survey comprises parallel north-south video lines covering the whole mound. In line

221 with the image sampling analysis methodology established herein, a minimum of number of

222 images $(X)$ were extracted from the T4 ROV video dataset with an equal number of images

223 extracted from each video line to ensure a homogenous spread of images across the Piddington

224 Mound surface. The video lines covering 100\% of the mound, offer a comparison of the T1

225 Piddington Mound mosaic after a 4-year interval and in survey design is comparable to "SD1

226 - random points".

227 Each extracted image was manually inspected. A cell $(25 \mathrm{~cm} \times 25 \mathrm{~cm})$ is overlaid around the

228 area of the photo where the laser scales pointed (central field of view) and a manual

229 classification was applied using the same classifiers as the T1 ROV video data set:

230 "hemipelagic sediment with dropstones", "coral rubble", "hemipelagic sediment", "dead coral

231 framework" and "live coral framework". The total number of cells from each class were

232 counted and their proportion determined. 


\section{Results}

\subsection{Seabed classification}

235 Figure 3 shows the classified fishnet over the Piddington Mound. 6 classes exist: "hemipelagic

236 sediment with dropstones", "coral rubble", "hemipelagic sediment", "dead coral framework",

237 "live coral framework" and "no data". These classes are described in Table 2. There are 5637

238 cells across the surface of Piddington Mound with the most common being "coral rubble" (36.1

$239 \pm 3.13 \%)$ and "dead coral framework" $(31.6 \pm 2.74 \%)$. The least common cell-types are

240 "hemipelagic sediment" $(1.1 \pm 0.09 \%)$ and "hemipelagic sediment with dropstones" $(6.7 \pm$

$2410.58 \%$ ). The "live coral framework" cells cover $16.3 \pm 1.42 \%$ of the mound surface. While the

242 "coral rubble" cell-type is found across the mound surface, it is typically concentrated around

243 the mound perimeter and on the mound summit. The "live coral framework" cells occur most

244 frequently towards the north of the mound. The "dead coral framework" can be found on the

245 mound flanks. For the remainder of the text, the proportions of all observed cell-types on the

246 Piddington Mound are referred to as the control proportion.

<Insert Table 2>

$249 \quad 3.2 \quad$ Image sampling analysis

250 Sample size estimation according to Thompson (1987), reveals a sample size, $X$ ( $\mathrm{n}$ if $\mathrm{d}=0.05)$,

251 of 510 as a minimum sample size to reliably replicate, with a confidence level of $95 \%$, the

252 proportion of facies in the total of 5637 classified cells in the $0.25 \mathrm{~m}^{2}$ fishnet overlay on the

253 T1 Piddington Mound video-mosaic. The number of categories in our sample size is 6 which 254 is greater than the required minimum of 3. 
255 Figure 5 shows the results of the image sampling analysis for each survey design (more 256 information can be found in the supplementary data supplied with the online version) as facies

257 sampling curves. Survey design "SD1 - random points" (Fig. 5A) represents maximum video 258 coverage and thus the ability to drop 510 random points anywhere across the Piddington 259 Mound surface. This survey design resulted in a 5.9\% total difference in facies from the control, 260 namely of the actual proportion of all cells covering the Piddington Mound. The maximum 261 difference in an individual class is $2.9 \%$ ("dead coral framework") with an average class 262 difference of $1.2 \%$.

\section{$<$ Insert Figure $5>$}

263 Survey design "SD2 - south to north transect" (Fig. 5B) represents 510 random image sampling 264 points anywhere along a straight, individual ROV video line from the southern end to the northern end of the Piddington Mound. The line is $50 \mathrm{~m}$ in length taking approx. 3.2 minutes for an ROV to complete at 0.5 knots. This survey design resulted in a total of $22.5 \%$ difference to that of the actual proportion of all cells covering the Piddington Mound. The maximum difference in an individual class is $6.3 \%$ ("dead coral framework") with an average class difference of $4.1 \%$.

Survey design "SD3 - east to west transect" (Fig. 5C) represents 510 random image sampling points anywhere along a straight, individual ROV video line from the eastern edge to the western edge of the Piddington Mound. The line is $40 \mathrm{~m}$ in length taking approx. 2.5 minutes

273 for an ROV to complete at 0.5 knots. This survey design resulted in a total of $11.8 \%$ difference to that of the actual proportion of all cells covering the Piddington Mound. The maximum difference in an individual class is $5.8 \%$ ("hemipelagic sediment with dropstones") with an average class difference of $1.7 \%$. 
277 Survey design "SD4 - northwest-southeast diagonal transect" (Fig. 5D) represents 510 random 278 image sampling points anywhere along a straight, individual ROV video line from the north279 western edge to the south-eastern edge of the Piddington Mound. The line is $40 \mathrm{~m}$ in length 280 taking approx. 2.5 minutes for an ROV to complete at 0.5 knots. This survey design resulted 281 in a total of $22.4 \%$ difference to that of the actual proportion of all cells covering the Piddington

282 Mound. The maximum difference in an individual class is 7.6\% ("live coral framework") with an average class difference of $2.9 \%$.

284 Survey design "SD5 - 2 lines" (Fig. 5E) represents 510 random image sampling points anywhere along 2 straight ROV video lines (SD2 + SD3) intersecting each other at the summit of the Piddington Mound. This survey covers a line length of $90 \mathrm{~m}$ taking approx. 5.8 minutes for an ROV to complete at 0.5 knots. This survey design resulted in a total of $12.4 \%$ difference to that of the actual proportion of all cells covering the Piddington Mound. The maximum difference in an individual class is $4.7 \%$ ("hemipelagic sediment with dropstones") with an average class difference of $2.0 \%$.

291 Survey design "SD6 - 3 straight, parallel line grid” (Fig. 5F) represents 510 random image sampling points anywhere along 3 straight, parallel ROV video lines traversing the Piddington Mound in a north-south orientation. This survey covers a line length of $130 \mathrm{~m}$ taking approx.

2948.4 minutes for an ROV to complete at 0.5 knots. This survey design resulted in a total of $29522.9 \%$ difference to that of the actual proportion of all cells covering the Piddington Mound. 296 The maximum difference in an individual class is $9.7 \%$ ("hemipelagic sediment with 297 dropstones") with an average class difference of $3.8 \%$.

298 Survey design "SD7 - 3 summit-crossing lines" (Fig. 5G) represents 510 random image 299 sampling points anywhere along 3 straight, parallel ROV video lines traversing the Piddington 300 Mound (SD2 + SD3 + SD4). This survey covers a line length of $130 \mathrm{~m}$ taking approx. 8.4 
minutes for an ROV to complete at 0.5 knots. This survey design resulted in a total of $11.1 \%$

302 difference to that of the actual proportion of all cells covering the Piddington Mound. The

303 maximum difference in an individual class is $3.4 \%$ (“dead coral framework") with an average

304 class difference of $1.8 \%$.

305 Survey design "SD8 - horizontal grid” (Fig. 5H) represents 510 random image sampling points

306 anywhere along an east-west grid of ROV video lines covering the Piddington Mound. This

307 survey covers a line length of 320 m taking approx. 20.7 minutes for an ROV to complete at

3080.5 knots. This survey design resulted in a total of $5.8 \%$ difference to that of the actual

309 proportion of all cells covering the Piddington Mound. The maximum difference in an

310 individual class is $2.9 \%$ ("coral rubble") with an average class difference of $1.1 \%$. It is also

311 worth noting that there was $0 \%$ cell difference in 3 classes.

312 Survey design "SD9 - spiral" (Fig. 5I) represents 510 random image sampling points anywhere

313 along a spiral or conical ROV video line circling from the mound perimeter to the mound flank

314 to the mound summit. This survey covers a line length of $240 \mathrm{~m}$ taking approx. 15.5 minutes

315 for an ROV to complete at 0.5 knots. This survey design resulted in a total of $13.4 \%$ difference

316 to that of the actual proportion of all cells covering the Piddington Mound. The maximum

317 difference in an individual class is $4.1 \%$ ("dead coral framework") with an average class

318 difference of $2.2 \%$.

319 Survey design "SD10 - actual survey example" (Fig. 5J) represents 510 random image

320 sampling points along an actual ROV reconnaissance dive video line over the Piddington

321 Mound. This survey covers a line length of $1283 \mathrm{~m}$ taking 83 minutes for the ROV to complete

322 at 0.5 knots. This survey design resulted in a total of $17.7 \%$ difference to that of the actual

323 proportion of all cells covering the Piddington Mound. The maximum difference in an 
324 individual class is $6.7 \%$ ("hemipelagic sediment with dropstones") with an average class difference of $3.4 \%$.

\subsection{Temporal variability analysis}

328 Figure 6 and Table 3 show the results of the temporal variability of the Piddington Mound surface data based on a comparison to class determinations in the T1 and T4 video survey data.

330 The minimum number of random samples needed to characterise the mound with a 0.95

331 probability of being within 0.05 of the class proportions is 510. Here, 622 images are used which marginally increases accuracy above $95 \%$ confidence. The most common T4 cell-types are "coral rubble" (43.6\%) and "dead coral framework" (37.3\%). The "live coral framework"

334 cell-type occurs $16.7 \%$ of the time. The least common cell types are "hemipelagic sediment" $335(1 \%)$ and "hemipelagic sediment with dropstones" (1.4\%). An important limiting factor of this 336 result is that the error bars developed (Fig. 6 and Table 3) must be considered when comparing 337 the T1 and T4.

\section{Discussion}

$341 \quad 4.1 \quad$ Seabed imagery for cold water coral mound characterisation

342 Numerous CWC mounds have been studied incorporating video observations from ROV-

343 mounted camera systems in various different ways: oblique-angled, forward-facing camera 
344 (Foubert et al., 2005), downward-facing camera (Huvenne et al., 2016), both downward-facing and oblique-angled, forward-facing cameras (Dolan et al., 2008; Guinan et al., 2009) and up to 3 cameras (Savini et al., 2014; Vertino et al., 2010). In this study, we focus only on downward facing cameras and we question the effect of the amount of imagery used and the survey design by which it was collected which often varies from study to study. Here, the amount and survey design of seabed imagery acquisition is examined to put forward a survey-feasible methodology for characterising the surface of CWC mounds.

4.1.1 How much seabed imagery is needed to characterise the Piddington Mound? In the deep sea, sampling and surveying opportunities are limited due to the availability, financial expense and weather-dependency of ship-time on research vessels. As a result, deepmarine data collection is strictly prioritised by urgency of data needs, quite often to meet the needs of funding sources. As such, studies have used "single-pass" (individual line, typically straight) video lines across the surface of CWC mounds to ground truth their surface (e.g. Foubert et al., 2005; Huvenne et al., 2016). While this offers the opportunity to increase the geographical range of the study, it decreases the potential confidence and representativeness of the study. This leads to the question, how much imagery is actually needed to create a reliable representation of the surface of a CWC mound?

362 Based on the seabed classification (Figure 3), the mound surface sediment facies proportion of $3630.25 \mathrm{~cm}^{2}$ cell-types on the Piddington Mound are known. Our sample size estimation shows 364 that 510 is the minimum number of $0.25 \mathrm{~cm}^{2}$ images needed to accurately determine the 365 proportion of identified classes on the Piddington Mound. Survey design "SD1 - random 366 points" represents the ability to drop 510 random points anywhere on the Piddington Mound, thus utilizing the same video coverage as the T1 ROV video data set (full mound coverage). 
368 Therefore, it can be used to assess and ground-truth the accuracy of the determined sample size. A comparison of the control proportion (Figure 5; All T1) with survey design "SD1 random points" (Figure 5) shows that this estimation is within 5.9\% of the correct proportion

371 of cell-types observed on the Piddington Mound, in line with the aimed probability (at least

3720.95 that all estimates are within 0.05 of the multinomial proportions) of this dataset and gives

373 the most reliable representation of the mound surface of all the survey designs tested. The "SD1

374 - random points" survey could be accomplished by sub-sampling a video-mosaic (100\% mound coverage) which, perhaps not surprisingly, is the most robust approach to characterising the mound surface. This could alternatively be accomplished by the use a yo-yo drop camera.

377 Vertino et al. (2010) examine CWC meso- and macro-scale habitats at the Santa Maria di Leuca 378 Coral Province, a clear example of the utilisation of dense ROV video coverage on CWC mounds and associated habitats to produce detailed studies. The detail revealed by studies with dense video coverage per CWC mound raises the question: are the spatial representation of "single-pass" video line surveys across CWC mounds enough? And conversely, with strict research cruise schedules, at what point does video coverage become excessive?

Single-pass ROV video lines across CWC mounds are common (i.e. Dolan et al., 2008; Lim, 2017). As such, 3 different straight line survey designs are tested here ("SD2 - south to north", "SD3 - east to west" and "SD4 - northwest-southeast diagonal transect") (Fig. 4 and 5). With an average of $18.9 \%$ total difference in cell-type proportions from the control proportion, single-pass surveys appear to yield the least representative results. This is expected given the reduced spatial representation of such survey designs. Two of these survey designs ("SD2 south to north" and "SD4 - northwest-southeast diagonal transect") produce a total difference of $22.5 \%$ and $22.4 \%$ in cell-type proportion from the control proportion, while "SD3 - east to west" produces a total difference of $11.8 \%$. The ring-like cell-type clustering that exists on the Piddington Mound (Lim et al., 2017) appears to have an influence on this result as the course 
393 of the east to west line happens to cover an area with similar proportions to the control 394 proportion. This is evidenced by approximately $50 \%$ of the total difference of this survey 395 design resulting from 1 individual facies.

396 "SD5 - 2 lines" demonstrates the effect of adding a second line to one of these single-pass ROV 397 video lines, in this case SD2 and SD3. This shows an increase in accuracy of $6.5 \%$ from single 398 pass surveys $(18.9 \%)$ to the 2 line survey (12.4\%). "SD7 - 3 summit crossing lines" 399 demonstrates the effect of adding a third line (SD2 + SD3 + SD4) to these 2 lines. This shows 400 an increase in accuracy of $1.3 \%$ from the 2 line (12.4\%) (SD $2+$ SD3) survey to the 3 line 401 (11.1\%) (SD2 + SD3 + SD4) survey. As such, doubling the number of lines from 1 to 2 402 increased the accuracy by $6.5 \%$ while adding the third line increased the accuracy by just $1.3 \%$ 403 while adding 2.6 minutes of extra survey time. Interestingly, a comparison of these 3 summitcrossing lines with 3 lines collected in a grid (SD6), both surveys the same length and time (130 m; 8.4 minutes), highlights the effect of survey design on results where "SD6 - 3 line 406 grid" produced notably less-accurate results (22.9\% total difference in facies proportions from 407 the control proportion).

408 Another common survey design is following the geomorphology of the CWC mound (i.e. 409 Guinan et al., 2009) or some other known characteristic. In the case of the Piddington Mound, 410 survey design "SD9 - spiral" (Fig. 4 and 5) follows both the bathymetry and ring-like growth 411 already observed on the Piddington Mound (Lim et al., 2017), circling through the mound 412 perimeter, flank and summit. This cone-like survey design yields a $13.4 \%$ total cell-type 413 proportion difference from the control proportion. The accuracy of this result is probably due 414 to the influence of prior knowledge on survey design.

415 Survey design "SD10 - actual survey" defines the navigation path of an ROV on a 416 reconnaissance dive over the Piddington Mound when it was first discovered and initially 
417 investigated (Wheeler and shipboard party, 2011) (Fig. 4 and 5). This survey design yields a

$41817.7 \%$ total cell-type proportion difference from the control proportion. It represents a real-life

419 example of survey design without the influence of prior knowledge or mapping of the CWC

420 mound. This survey design (or lack of) resulted in relatively a large (7.6\%) over-estimation of

421 "live coral framework" cell-types. This sampling bias may be typical of reconnaissance video

422 investigations when discovering new seabed features as scientists may preferentially

423 concentrate the cameras on the live proportion of the feature that is of more interest to them.

424 Another short-coming of this survey design, and probably a result of the same sampling bias,

425 is that 2 entire classes were not seen in the video observation ("hemipelagic sediment with

426 dropstones" and "hemipelagic sediment"). Interestingly, this survey covered a line length of

$4271283 \mathrm{~m}$ (83 survey minutes), over $1000 \mathrm{~m}$ more than the aforementioned surveys designs. As

428 such, this once again highlights the importance of survey design over line length.

Probably the most well-known survey design, but apparently least-applied in the case of CWC mounds is survey design "SD8 - horizontal grid" (Fig. 4 and 5). In this example, the grid is made up of a series of mound-traversing lines spaced approximately $5 \mathrm{~m}$ apart where the end of each line is connected to the start of the next line. This survey design yields a $5.8 \%$ total cell-type proportion difference from the control proportion, the most representative proportion of the study. An additional positive of this survey design is that it estimated the exact proportion of individual cell-types for 3 classes ("hemipelagic sediment with dropstones", "hemipelagic sediment" and "live coral framework"). Interestingly, it also yields a similar result to survey design "SD1 - random points" (5.9\%) which represents full-mound video coverage. With line spacing of approx. $1 \mathrm{~m}$, it took $\sim 8$ hours to collect the full-mound video coverage (Wheeler and shipboard party, 2011). Assuming a survey speed of 0.5 knots to collect survey design "SD8 440 horizontal grid" (line length of $320 \mathrm{~m}$ ), it would take 20.7 minutes to collect this ROV video 441 data, a vast improvement from $\sim 8$ hours for the same representation of surface facies 
442 proportions. In addition, this technique appears to be unbiased by the significant clustering 443 found on the Piddington Mound (Lim et al., 2017).

4.2 What is the temporal variability of Piddington Mound and its implication for samples?

The T4 ROV-video dataset was collected over the Piddington Mound 4 years after the T1 survey (2015) covering the entire mound surface with the same downward-facing camera array. To assess mound surface change over this period, 622 random images are classified (a minimum of 510 are needed) according to the image sampling technique established above using the same classifiers. The survey design, similar to the T1 ROV video data set, covers the entire mound surface by a $1 \mathrm{~m}$ spaced line grid. Thus, the accuracy of this data is similar to that of survey design "SD1 - random points" (Fig. 5).

The T4 ROV video dataset exhibits a change of $19 \%$ of the total mound surface in comparison to the T1 ROV video dataset. This change has taken place over 4 years $(2011-2015)$ and is evident at a $25 \mathrm{~cm}^{2}$ resolution. The "live coral framework" cell-type remains relatively constant, increasing by only $0.4 \%$ over the 4 years $(+0.1 \%$ per year). A minute increase is expected given the slow growth rates (15 - $30 \mathrm{~mm} \mathrm{yr}^{-1}$ ) observed in Lophelia (Gass and Roberts, 2006; Larcom et al., 2014; Orejas et al., 2008). Similarly, Huvenne et al. (2016) show that after ten years, the amount of live coral found on the Darwin Mounds, the only other known example of small-sized CWC mounds in the NE Atlantic, also remains the same. The "normal" proportion of live coral per Darwin Mound is $\sim 45-55 \%$, sizably greater than that found here on the Piddington Mound.

463 The "hemipelagic sediment" cell-type also remains relatively constant $(-0.2 \%$ over 4 years $)$ given the minute change and size of the potential error margin (Table 3). This facies is typically found in the lee of "live coral framework" cell-types (Fig. 3) where it is protected from 
resuspension by the current (Lim et al., 2017). As such, given the fact that the proportion of

467 "live coral framework" cells have not changed, it seems likely that the proportion of

468 "hemipelagic sediment" cell-type would remain the same.

469 The "coral rubble" cell-type increased the most (7.5\%) at a rate of $1.9 \%$ per year, assuming a constant rate of change. Given the dominance of the "coral rubble" cell-type on Piddington Mound in 2011, it is likely to see a change in the proportion of this class. The source of this coral rubble is likely to be as a result of the biological or physical erosion of the "dead coral framework" class (Lim et al., 2017) or on-mound (re)exposure and redistribution through benthic erosion and transport processes.

Interestingly, the proportion of "dead coral framework" cell-type increased by $5.7 \%$ (a rate of $1.4 \%$ per year). If this class is both contributing to the "coral rubble" class and increasing relative to the T1 "dead coral framework" class, then it can be assumed that it changed by at least $5.7 \%$ and at a minimum of $1.4 \%$ per year. Given the low growth rate of Lophelia mentioned earlier, it is unlikely that the source of the increased "dead coral framework" coverage is entirely from the degradation of the "live coral framework" cell-type. It is therefore suggested that this increase is possibly through "dead coral framework" exhumation by currents removing covering sediment. Although there has been impact of demersal trawling on the seabed in the area (Foubert et al., 2005; Wheeler, Beck, et al., 2005), the Belgica Mound

484 Province is now an SAC (special area of conservation). As such, it less likely that trawling has 485 impacted the movement of dead coral framework on the mound during the course of the study.

The proportion of the "sediment and dropstone" class decreases the most $(-5.3 \%)$ at a rate of $4871.3 \%$ per year. Given the mound-perimeter occurrence of this class and the dominance of the 488 "coral rubble" on the steepest parts of the mound (flanks), it is likely that this decrease is due 489 to burial by coral rubble where the coral rubble (or freshly eroded coral rubble from dead coral 
490 frameworks) roll from the steepened mound flanks to the edges of the mound where the slope

491 decreases and "sediment and dropstone" cell-types are common (Lim et al., 2017).

492 Based on the results herein and cautiously assuming a linear rate of change of a total mound 493 surface change of $4.8 \%$ per year, then in just over 20 years, this suggests the entire Piddington 494 Mound surface will change. Thus, if physical and image (video or photographic) samples are 495 taken 5 years apart on Piddington Mound, a change of 25\% (and 50\% after 10 years) on the 496 mound surface influences whether or not these samples consistently represent the mounds' 497 status in the contemporary environment. This, coupled with the heterogeneity observed on the 498 CWC mounds, positioning error margins (e.g. $\sim 2 \mathrm{~m}$ with some calibrated USBL systems in 499 deep water) and inconsistencies of repeat video acquisition (Purser, 2015) contests the validity 500 of interpretation from surface samples on similar CWC mounds. It is therefore recommended 501 that data from various survey campaigns should be treated cautiously as they may not represent 502 the "contemporary" environment. As such, we strongly recommend to use samples collected 503 during the same survey to represent the contemporary environment (e.g. samples collected in 5042017 to be used only with video coverage from 2017) if possible.

505 Centimetre-scale, remotely-sensed mapping is becoming more common in the marine 506 environment. As such, observations from video data should be equally as accurate. Oblique 507 camera data acquisition induces positional errors where there is an offset between the field of 508 view of the camera and the positioning beacon (e.g. USBL) thus giving an incorrect position 509 for oblique camera video observation. This error is a function of camera obliqueness, rotation 510 of the camera-mounted platform (e.g. ROV) around its axis, seabed slope and height of camera 511 from seabed and is therefore not constant nor easily reconciled. For relevant example, oblique 512 camera data has been utilized in a temporal study of a CWC mound, offshore Norway, which 513 highlights the inconsistencies of repeat surveys using oblique camera (e.g. viewing the same 514 part of the mound from different angles) (Purser, 2015). As such, we would like to recommend 
the use of downward-facing camera for temporal-based studies of CWC habitats (and other dynamic marine habitats) as positioning of the camera is not influenced by rotation of the

517 camera around its axis, the angle at which it views the seabed is always the same $\left(0^{\circ}\right)$ and is

518 not influenced by seabed slope in the same way as oblique camera.

\section{Conclusion}

520 This study presents an assessment of video survey design specific to a CWC mound (the

521 Piddington Mound of the Moira Mounds, NE Atlantic) to assess both differences in surface

522 facies proportion and temporal facies proportion. The technique presented is developed with particular consideration for the financial, temporal and sea-state dependant nature of deep sea research to maximise resolution and spatial coverage. Known proportions of CWC-typical facies on the Piddington Mound were used to determine the minimum number of images needed to characterise the surface of similar-sized CWC mounds with the same number of classes using downward-facing camera. This allows for a standardised approach to surveying and studying CWC mounds through video and comparison of mounds in different geographic settings and in time at $25 \mathrm{~cm}^{2}$ resolution. A comparison of different common survey designs show that single-pass video are the least-representative and highly-influenced by the

531 heterogeneity, typical of CWC mounds, despite being commonly utilised in research.

532 Following bathymetry or known features on CWC mounds is another common survey design

533 but does not yield the most accurate results. The most representative results were yielded from either fully video mosaicking a mound or using a grid of spaced lines. However, a grid of lines in this case requires $1 / 16$ of the time required for video mosaicking an entire mound while 536 yielding similar results.

537 The developed technique was applied to the Piddington Mound 4 years later to assess the change in proportions of facies across the mound surface. With a mound surface change of 
$4.8 \%$ per year, the mound surface has changed by almost $20 \%$ from 2011 to 2015 . The greatest

540 change was in the "coral rubble" class $(7.5 \%)$ followed by "dead coral framework" and

541 "sediment and dropstone" classes. These classes are affected by strong currents as mobile or

542 exhumed substrates. Similar to other mounds, the proportion of "live coral framework" class

543 remained the same over the 4-year period as anticipated for a sessile slow growing organism.

544 Although assuming a linear rate of change, we suggest that in approx. 20 years, $100 \%$ change

545 in the surface of the Piddington Mound. Thus, samples taken from the mound 5 years apart

546 (with a 25\% mound surface change), makes the samples inconsistent and therefore not

547 representative of the contemporary mound status. We also stress that in utilising this technique,

548 the potential error bars must be taken into consideration when comparing between data sets.

549 Finally, we highlight the suitability of downward-facing camera for high-resolution repeat 550 surveys for temporal variability purposed due to the many short-comings of temporal-based, 551 oblique-camera surveys.

\section{Acknowledgements}

554 The authors would like to sincerely thank Boris Dorschel for his extremely useful input and

555 proofing of this work, Evan Edinger and another anonymous reviewer for their timely and 556 insightful reviews. We would like to thank the crew and officers of ROV Holland 1 and RV

557 Celtic Explorer for assistance in collecting high resolution, accurately positioned data. Ship 558 time on the RV Celtic Explorer was funded by the Marine Institute under the 2011 and 2015 559 Ship Time Programme of the National Development Plan. Mohit Tunwal (UCC) is thanked for 560 mathematical proofing. 
562 Angers, C., 1974. A graphical method to evaluate sample sizes for the multinomial distribution.

563 Technometrics 16, 469-471, http://dx.doi.org/10.1080/00401706.1974.10489219.

564 Beyer, A., Schenke, H.W., Klenke, M., Niederjasper, F., 2003. High resolution bathymetry of

565 the eastern slope of the Porcupine Seabight. Marine Geology 198, 27-54,

566 http://dx.doi.org/10.1016/S0025-3227(03)00093-8.

567 Burt, P.J., Adelson, E.H., 1983. A Multiresolution Spline with Application to Image Mosaics.

568 Acm Transactions on Graphics 2, 217-236, Doi 10.1145/245.247.

569 Chitre, M., Shahabudeen, S., Stojanovic, M., 2008. Underwater acoustic communications and 570 networking: Recent advances and future challenges. Marine Technology Society Journal 42, 571 103-116, http://dx.doi.org/10.4031/002533208786861263.

572 Correa, T.B.S., Eberli, G.P., Grasmueck, M., Reed, J.K., Correa, A.M.S., 2012. Genesis and 573 morphology of cold-water coral ridges in a unidirectional current regime. Marine Geology 326, 574 14-27, 10.1016/j.margeo.2012.06.008.

575 Davies, A.J., Guinotte, J.M., 2011. Global Habitat Suitability for Framework-Forming Cold576 Water Corals. PLoS ONE 6, e18483, 10.1371/journal.pone.0018483.

577 Davies, A.J., Wisshak, M., Orr, J.C., Roberts, J.M., 2008. Predicting suitable habitat for the 578 cold-water coral Lophelia pertusa (Scleractinia). Deep-Sea Research I 55, 1048-1062, 579 http://dx.doi.org/10.1016/j.dsr.2008.04.010.

580 De Mol, B., Kozachenko, M., Wheeler, A.J., Alvares, H., Henriet, J.-P., Olu-Le Roy, K., 2007. 581 Thérèse Mound: a case study of coral bank development in the Belgica Mound Province, 582 Porcupine Seabight. International Journal of Earth Sciences 96, 103-120, 583 http://dx.doi.org/10.1007/s00531-005-0496-X.

584 Dolan, M.F.J., Grehan, A.J., Guinan, J.C., Brown, C., 2008. Modelling the local distribution 585 of cold-water corals in relation to bathymetric variables: Adding spatial context to deep-sea 586 video data. Deep-Sea Research I 55, 1564-1579, http://dx.doi.org/10.1016/j.dsr.2008.06.010.

587 Dorschel, B., 2003. Late Quaternary Development of a deep-water Carbonate Mound in the 588 northeast Atlantic, RCOM-Bremen. University of Bremen, bremen, p. 90.

589 Dorschel, B., Wheeler, A.J., Huvenne, V.A.I., de Haas, H., 2009. Cold-water coral mounds in 590 an erosive environmental setting: TOBI side-scan sonar data and ROV video footage from the 591 northwest Porcupine Bank, NE Atlantic. Marine Geology 264, 218-229, 592 10.1016/j.margeo.2009.06.005.

593 Douarin, M., Sinclair, D.J., Elliot, M., Henry, L.-A., Long, D., Mitchison, F., Roberts, J.M., 594 2014. Changes in fossil assemblage in sediment cores from Mingulay Reef Complex (NE 595 Atlantic): Implications for coral reef build-up. Deep Sea Research Part II: Topical Studies in 596 Oceanography 99, 286-296, http://dx.doi.org/10.1016/j.dsr2.2013.07.022. 
Dullo, W.-C., Flögel, S., Rüggeberg, A., 2008. Cold-water coral growth in relation to the 598 hydrography of the Celtic and Nordic European continental margin. Marine Ecology Progress Series 371, 165-176, 10.3354/meps07623.

600 Eisele, M., Hebbeln, D., Wienberg, C., 2008. Growth history of a cold-water coral covered carbonate mound - Galway Mound, Porcupine Seabight, NE-Atlantic. Marine Geology 253, 160-169, 10.1016/j.margeo.2008.05.006.

603

604

605

606

607

608

609

610

611

612

613

614

615

616

617

618

619

620

621

622

623

624

625

626

627

628

629

630

631

632

633

634

635

636

Ferrer, J., Elibol, A., Delaunoy, O., Gracias, N., Garcia, R., 2007. Large-area photo-mosaics using global alignment and navigation data, MTS/IEEE OCEANS Conference, Vancouver, Canada, pp. 1-9, http://dx.doi.org/10.1109/OCEANS.2007.4449367.

Foubert, A.T.G., Beck, T., Wheeler, A.J., Opderbecke, J., Grehan, A., Klages, M., Thiede, J., Henriet, J.-P., Polarstern ARK-XIX/3a shipboard party, 2005. New view of the Belgica Mounds, Porcupine Seabight, NE Atlantic: preliminary results from the Polarstern ARKXIX/3a ROV cruise, in: Freiwald, A., Roberts, J.M. (Eds.), Deep-water corals and Ecosystems, . Springer-Verlag, Berlin Heidelberg, pp. 403-415.

Freiwald, A., 2002. Reef-Forming Cold-Water Corals, in: Wefer, G., Billett, D.S.M., Hebbeln, D., Jørgensen, B.B., van Weering, T.C.E. (Eds.), Ocean Margin Systems, Hanse Conference on Ocean Margin Systems (2000: Delmenhorst, Germany) ed. Springer, Berlin Heidelberg New York, pp. 365-385, http://dx.doi.org/10.1007/978-3-662-05127-6_23.

Freiwald, A., Fosså, J.H., Grehan, A., Koslow, T., Roberts, J.M., 2004. Cold-water Coral Reefs, NEP-WCMC, Cambridge, UK, p. 88, http://hdl.handle.net/20.500.11822/8727.

Freiwald, A., Wilson, J.B., 1998. Taphonomy of modern, deep, cold-temperate water coral reefs. Historical Biology 13, 37-52, http://dx.doi.org/10.1080/08912969809386571.

Gass, S.E., Roberts, J.M., 2006. The occurrence of the cold-water coral Lophelia pertusa (Scleractinia) on oil and gas platforms in the North Sea: Colony growth, recruitment and environmental controls on distribution. Marine Pollution Bulletin 52, 549-559, http://dx.doi.org/10.1016/j.marpolbul.2005.10.002.

Guinan, J., Grehan, A.J., Dolan, M.F.J., Brown, C., 2009. Quantifying relationships between video observations of cold-water coral cover and seafloor features in Rockall Trough, west of Ireland. Marine Ecology Progress Series 375, 125-138, 10.3354/meps07739.

Henriet, J.P., Hamoumi, N., Da Silva, A.C., Foubert, A., Lauridsen, B.W., Rüggeberg, A., Van Rooij, D., 2014. Carbonate mounds: From paradox to World Heritage. Marine Geology 352, 89-110, http://dx.doi.org/10.1016/j.margeo.2014.01.008.

Huvenne, V.A., Tyler, P.A., Masson, D.G., Fisher, E.H., Hauton, C., Huhnerbach, V., Le Bas, T.P., Wolff, G.A., 2011. A picture on the wall: innovative mapping reveals cold-water coral refuge in submarine canyon. PLoS ONE 6, e28755, 10.1371/journal.pone.0028755.

Huvenne, V.A.I., Bett, B.J., Masson, D.G., Le Bas, T.P., Wheeler, A.J., 2016. Effectiveness of a deep-sea cold-water coral Marine Protected Area, following eight years of fisheries closure. Biological Conservation 200, 60-69, 10.1016/j.biocon.2016.05.030.

Huvenne, V.A.I., Beyer, A., de Haas, H., Dekindt, K., Henriet, J.-P., Kozachenko, M., Olu-Le Roy, K., Wheeler, A.J., participants, T.P.c., participants, C.c., 2005. The seabed appearance of 
different coral bank provinces in the Porcupine Seabight, NE Atlantic: results from sidescan sonar and ROV seabed mapping, in: Freiwald, A., Roberts, J.M. (Eds.), Cold-water Corals and Ecosystems. Springer-Verlag, Berlin Heidelberg, pp. 535-569, http://dx.doi.org/10.1007/3$640 \quad$ 540-27673-4_27.

641 Kinsey, J.C., Eustice, R.M., Whitcomb, L.L., 2006. A survey of underwater vehicle navigation: 642 Recent advances and new challenges, IFAC Conference of Manoeuvering and Control of 643 Marine Craft.

644 Kwatra, V., Schödl, A., Essa, I., Turk, G., Bobick, A., 2003. Graphcut textures: image and 645 video synthesis using graph cuts, ACM Transactions on Graphics (TOG). ACM, pp. 277-286, http://dx.doi.org/10.1145/882262.882264.

647 Larcom, E.A., McKean, D.L., Brooks, J.M., Fisher, C.R., 2014. Growth rates, densities, and 648 distribution of Lophelia pertusa on artificial structures in the Gulf of Mexico. Deep-Sea Research Part I-Oceanographic Research Papers 85, 101-109, 10.1016/j.dsr.2013.12.005.

Lavaleye, M., Duineveld, G., Lundälv, T., White, M., Guihen, D., Kiriakoulakis, K., Wolff, G.A., 2009. Cold-Water Corals on the Tisler Reef-preliminary observations on the dynamic reef environment. Oceanography 22, 76-84, http://dx.doi.org/10.5670/oceanog.2009.08.

Lim, A., 2017. Spatio-temporal patterns and controls on cold-water coral reef development: 654 the Moira Mounds, Porcupine Seabight, NE Atlantic, School of Biological, Earth and 655 Environmental Sciences. University College Cork, Cork Open Research Archive, p. 221, 656 http://hdl.handle.net/10468/4031.

657 Lim, A., Wheeler, A.J., Arnaubec, A., 2017. High-resolution facies zonation within a cold658 water coral mound: The case of the Piddington Mound, Porcupine Seabight, NE Atlantic. Marine Geology 390, 120-130, https://doi.org/10.1016/j.margeo.2017.06.009.

660 Lowe, D.G., 1999. Object recognition from local scale-invariant features, Computer vision, 661 1999. The proceedings of the seventh IEEE international conference on Computer Vision. Ieee, 662 pp. 1150-1157, http://dx.doi.org/10.1109/ICCV.1999.790410. Lundälv, T., Fosså, J.H., Buhl Mortensen, P., Jonsson, L.G., White, M., Guihen, D., Unnithan, 664 V., 2008. Development in a trawl-damaged coral habitat (Tisler reef, NE Skagerrak) during four years of trawl protection, 4th International Symposium on Deep-Sea Corals, Wellington, New Zealand, December 2008.

668 Mangini, A., Lomitschka, M., Eichstadter, R., Frank, N., Vogler, S., Bonani, G.G., Hajdas, I., 669 Pätzold, J., 1998. Coral provides age of deep water. Nature 392, http://dx.doi.org/10.1038/32804. and size of Lophelia pertusa coral reefs in mid-Norway in relation to seabed characteristics. Journal of the Marine Biological Association of the UK Volume 81, Issue 04, Aug 2001, 581597, http://dx.doi.org/10.1017/S002531540100426X.

674 Murphy, P., Wheeler, A.J., 2017. A GIS-based application of drainage basin analysis and 675 geomorphometry in the submarine environment: The Gollum Canyon System, North-east 676 Atlantic, in: Bartlett, D., Celliers, L. (Eds.), Geoinformatics for Marine and Coastal 
679 Orejas, C., Gori, A., Gili, J.M., 2008. Growth rates of live Lophelia pertusa and Madrepora 680 oculata from the Mediterranean Sea maintained in aquaria. Coral Reefs 27, 255-255, 10.1007/s00338-007-0350-7.

682 Orejas, C., Gori, A., Rad-Menendez, C., Last, K.S., Davies, A.J., Beveridge, C.M., Sadd, D., 683 Kiriakoulakis, K., Witte, U., Roberts, J.M., 2016. The effect of flow speed and food size on the 684 capture efficiency and feeding behaviour of the cold-water coral Lophelia pertusa. Journal of 685 Experimental Marine Biology and Ecology 481, 34-40, 10.1016/j.jembe.2016.04.002.

686 Purser, A., 2015. A Time Series Study of Lophelia pertusa and Reef Megafauna Responses to 687 Drill Cuttings Exposure on the Norwegian Margin. PLoS ONE 10, e0134076, 688 10.1371/journal.pone.0134076.

689 Purser, A., Larsson, A.I., Thomsen, L., van Oevelen, D., 2010. The influence of flow velocity 690 and food concentration on Lophelia pertusa (Scleractinia) zooplankton capture rates. Journal of Experimental Marine Biology and Ecology 395, 55-62, 10.1016/j.jembe.2010.08.013.

Raddatz, J., Rüggeberg, A., Liebetrau, V., Foubert, A., Hathorne, E.C., Fietzke, J., Eisenhauer, A., Dullo, W.-C., 2014. Environmental boundary conditions of cold-water coral mound growth over the last 3 million years in the Porcupine Seabight, Northeast Atlantic. Deep Sea Research Part II: Topical Studies in Oceanography 99, 227-236, http://dx.doi.org/10.1016/j.dsr2.2013.06.009.

697 Robert, K., Huvenne, V.A.I., Georgiopoulou, A., Jones, D.O.B., Marsh, L., D. O. Carter, G., 698 Chaumillon, L., 2017. New approaches to high-resolution mapping of marine vertical structures. Scientific Reports 7, 9005, 10.1038/s41598-017-09382-z.

700 Robert, K., Jones, D.O.B., Roberts, J.M., Huvenne, V.A.I., 2016. Improving predictive 701 mapping of deep-water habitats: Considering multiple model outputs and ensemble techniques. 702 Deep Sea Research Part I: Oceanographic Research Papers 113, 80-89, 703 http://dx.doi.org/10.1016/j.dsr.2016.04.008.

704

705

706

707

708

709

710

711

Roberts, J.M., Long, D., Wilson, J.B., Mortensen, P.B., Gage, J.D., 2003. The cold-water coral Lophelia pertusa (Scleractinia) and enigmatic seabed mounds along the north-east Atlantic margin: are they related? Marine Pollution Bulletin 46, 7-20, http://dx.doi.org/10.1016/S0025326X(02)00259-X.

Roberts, J.M., Wheeler, A.J., Cairns, S., Freiwald, A., 2009. Cold-water corals: the biology and geology of deep-sea coral habitats. Cambridge University Press, http://dx.doi.org/10.1017/CBO9780511581588.003.

Roberts, J.M., Wheeler, A.J., Freiwald, A., 2006. Reefs of the Deep: The Biology and Geology of Cold-Water Coral Ecosystems. Science 312, 543-547, http://dx.doi.org/10.1126/science.1119861.

Rüggeberg, A., Dullo, W.-C., Dorschel, B., Hebbeln, D., 2007. Environmental changes and growth history of a cold-water carbonate mound (Propeller Mound, Porcupine Seabight). International Journal of Earth Sciences 96, 57-72. 
Savini, A., Vertino, A., Marchese, F., Beuck, L., Freiwald, A., 2014. Mapping cold-water coral habitats at different scales within the Northern Ionian Sea (Central Mediterranean): an assessment of coral coverage and associated vulnerability. PLoS ONE 9, e87108, 10.1371/journal.pone.0087108.

721

Squires, D.F., 1964. Fossil coral thickets in Wairarapa, New Zealand. Journal Paleontol. 38, 904-915.

Thompson, S.K., 1987. Sample size for estimating multinomial proportions. The American Statistician 41, 42-46, http://dx.doi.org/10.2307/2684318.

Van Rooij, D., 2004. An integrated study of Quaternary sedimentary processes on the eastern slope of the Porcupine Seabight, SW of Ireland. Ghent University, http://dx.doi.org/1854/10815.

Vertino, A., Savini, A., Rosso, A., Di Geronimo, I., Mastrototaro, F., Sanfilippo, R., Gay, G., Etiope, G., 2010. Benthic habitat characterization and distribution from two representative sites of the deep-water SML Coral Province (Mediterranean). Deep-Sea Research Part Ii-Topical Studies in Oceanography 57, 380-396, 10.1016/j.dsr2.2009.08.023.

Wheeler, A.J., Beck, T., Thiede, J., Klages, M., Grehan, A., Monteys, F.X., Polarstern ARK XIX/3a Shipboard Party, 2005. Deep-water coral mounds on the Porcupine Bank, Irish margin: preliminary results from Polarstern ARK-XIX/3a ROV cruise, in: Freiwald, A., Roberts, J.M. (Eds.), Cold-water corals and Ecosystems. Springer-Verlag, Berlin, pp. 393-402, http://dx.doi.org/10.1007/3-540-27673-4_19.

Wheeler, A.J., Beyer, A., Freiwald, A., de Haas, H., Huvenne, V.A.I., Kozachenko, M., OluLe Roy, K., Opderbecke, J., 2007. Morphology and environment of cold-water coral carbonate mounds on the NW European margin. International Journal of Earth Sciences 96, 37-56, http://dx.doi.org/10.1007/s00531-006-0130-6.

Wheeler, A.J., Kozachenko, M., Beyer, A., Foubert, A.T.G., Huvenne, V.A.I., Klages, M., Masson, D.G., Olu-Le Roy, K., Thiede, J., 2005. Sedimentary processes and carbonate mounds in the Belgica Mound province, Porcupine Seabight, NE Atlantic, in: Freiwald, A., Roberts, J.M. (Eds.), Cold-water Corals and Ecosystems. Springer-Verlag, Berlin Heidelberg, pp. 533564, http://dx.doi.org/10.1007/3-540-27673-4_28.

Wheeler, A.J., Kozachenko, M., Henry, L.A., Foubert, A., de Haas, H., Huvenne, V.A.I., Masson, D.G., Olu, K., 2011. The Moira Mounds, small cold-water coral banks in the Porcupine Seabight, NE Atlantic: Part A-an early stage growth phase for future coral carbonate mounds? Marine Geology 282, 53-64, 10.1016/j.margeo.2010.08.006.

Wheeler, A.J., Kozachenko, M., Masson, D.G., Huvenne, V.A.I., 2008. Influence of benthic sediment transport on cold-water coral bank morphology and growth: the example of the Darwin Mounds, north-east Atlantic. Sedimentology 55, 1875-1887, 10.1111/j.13653091.2008.00970.x.

Wheeler, A.J., shipboard party, 2011. Vents \& Reefs deep-sea ecosystem study of the $45^{\circ}$ North MAR hydrothermal vent field and the cold-water coral Moira Mounds, Porcupine Seabight, Cruise report, p. 160. 
Wheeler, A.J., Stadnitskaia, A., 2011. Benthic Deep-Sea Carbonates. Developments in

758 Sedimentology 63, 397-455, http://dx.doi.org/10.1016/B978-0-444-53000-4.00006-8.

759 White, M., 2007. Benthic dynamics at the carbonate mound regions of the Porcupine Sea Bight

760 continental margin. International Journal of Earth Sciences 96, 1-9,

761 http://dx.doi.org/10.1007/s00531-006-0099-1.

762 Wienberg, C., Beuck, L., Heidkamp, S., Hebbeln, D., Freiwald, A., Pfannkuche, O., Monteys,

763 F.X., 2008. Franken Mound: facies and biocoenoses on a newly-discovered "carbonate mound"

764 on the western Rockall Bank, NE Atlantic. Facies 54, 1-24, 10.1007/s 10347-007-0118-0.

765 Wienberg, C., Hebbeln, D., Fink, H.G., Mienis, F., Dorschel, B., Vertino, A., López Correa,

766 M., Freiwald, A., 2009. Scleractinian cold-water corals in the Gulf of Cádiz-first clues about

767 their spatial and temporal distribution. Deep Sea Research Part I 56, 1873-1893,

768 doi:10.1016/j.dsr.2009.05.016.

769 Wilson, J.B., 1979. "Patch" development of the deep-water coral Lophelia pertusa (L.) on the 770 Rockall bank. Journal of the Marine Biological Association of the United Kingdom 59, 165771 177, http://dx.doi.org/10.1017/S0025315400046257.

772

773

774

775

776

777

778

779

780

781

782

783 


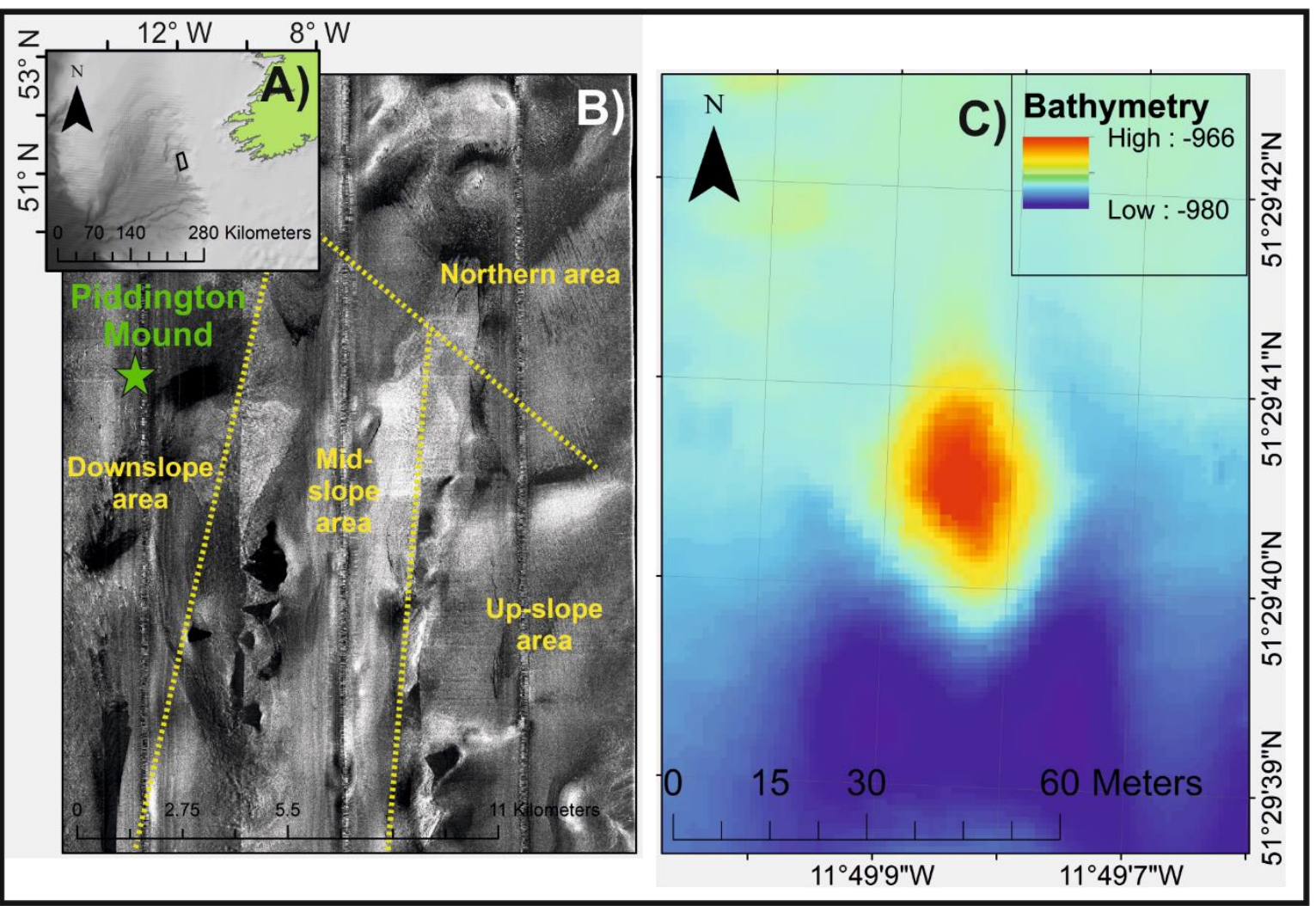

787 A) Location of Belgica Mound Province (BMP) Special Area of Conservation (SAC) (black

788 box), offshore SW Ireland; B) $30 \mathrm{kHz}$ TOBI side scan sonar imagery of the BMP SAC with

789 areas defined by Wheeler et al., (2011) in yellow and location of Piddington Mound indicated

790 by green star; C) Piddington Mound bathymetry (meters). 


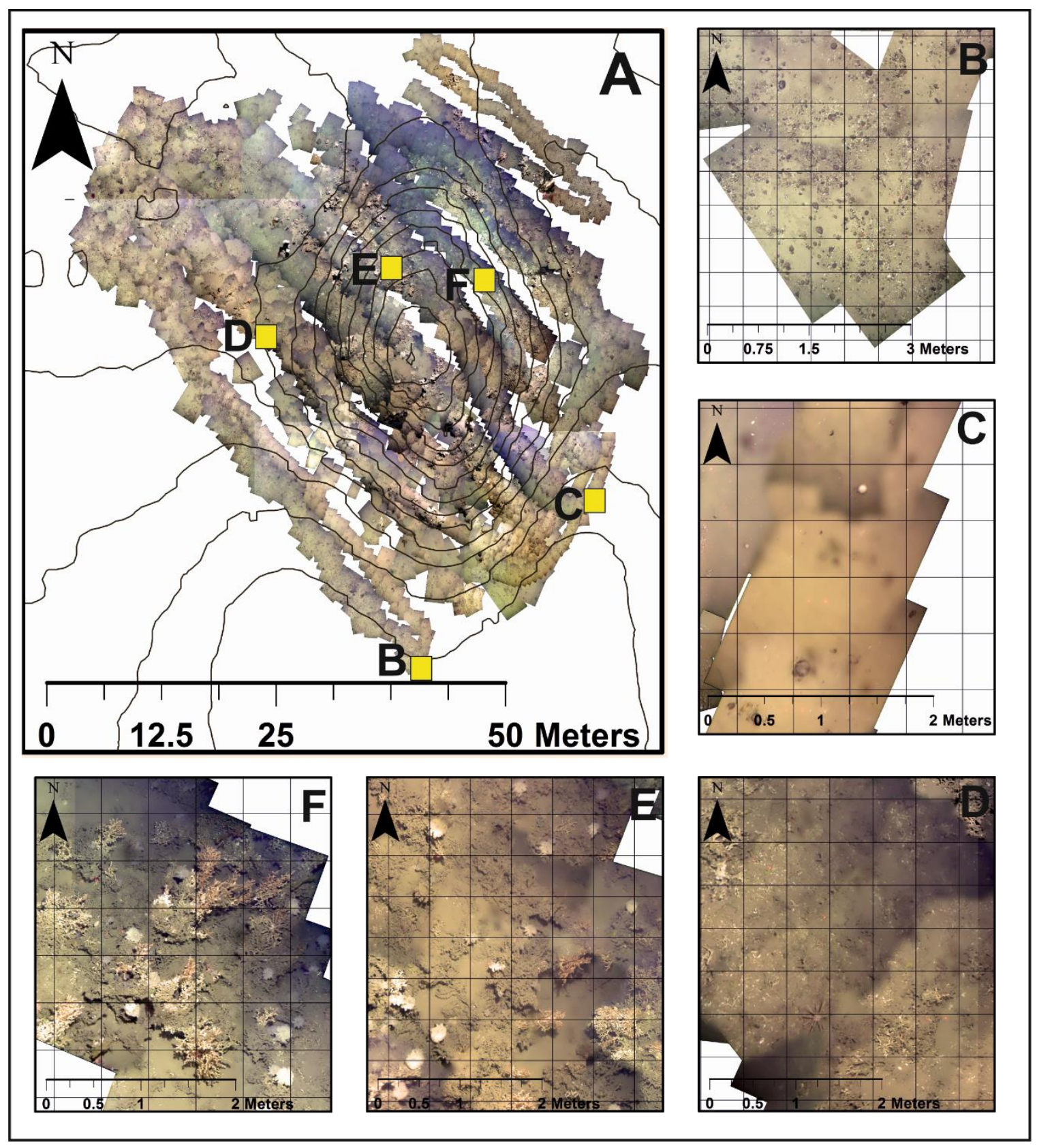

793 Figure 2 Map of the Piddington Mound video mosaic and examples of classes: A) mosaicked

794 area with $1 \mathrm{~m}$ contours superimposed, B) example of the "hemipelagic sediment with

795 dropstones" class, C) example of the "hemipelagic sediment" class, D) example of the "coral

796 rubble" class, E) example of the "dead coral framework" class, and F) example of the "live

797 coral framework" class. 


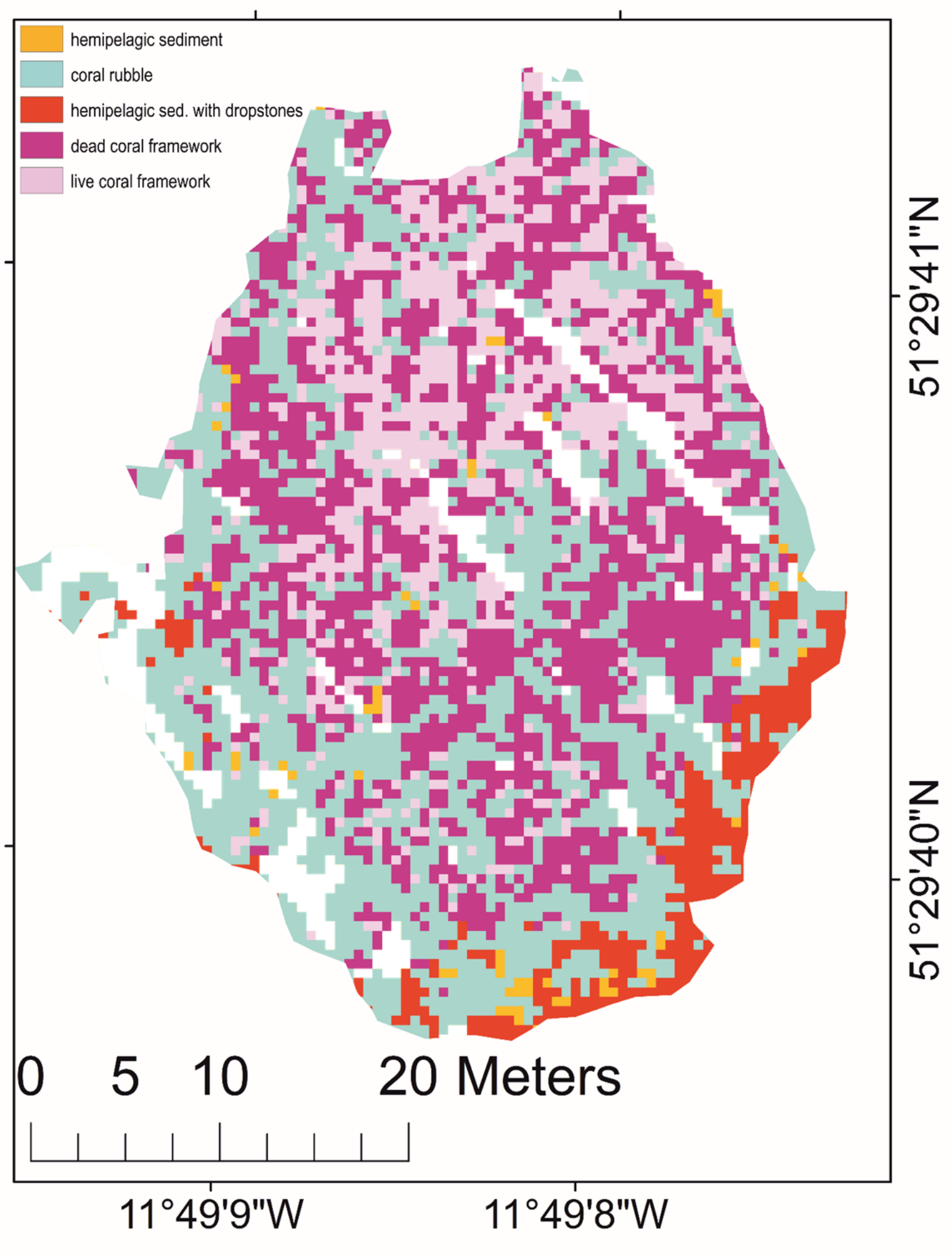

801 Blue = coral rubble cells; red=sediment and dropstone cells; orange $=$ hemipelagic sediment 802 cells; magenta=dead coral framework cells; and pink=live coral framework cells. 


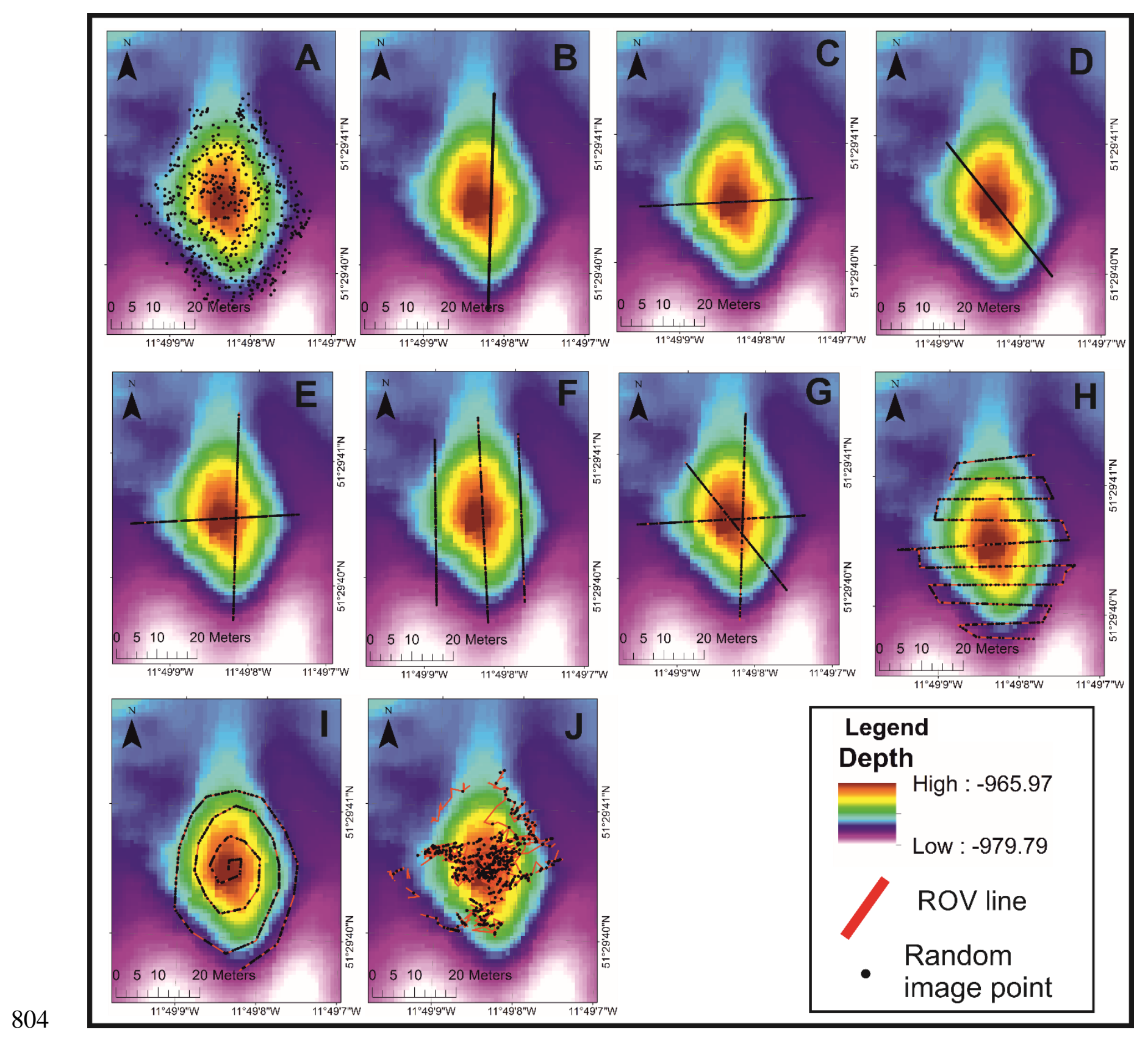

805

Figure 4 Video-survey designs facilitating the collection of $X=510$ random image points

806 along the survey lines

807 A) random points (SD1), B) south-north transect (SD2), C) east-west transect (SD3), D) 808 northwest-southeast diagonal transect (SD4), E) 2 lines (SD5), F) 3 straight, parallel line 809 grid (SD6), G) 3 summit-crossing lines (SD7), H) horizontal grid (SD8), I) spiral (SD9) $810 \quad$ and $J$ ) an actual survey transect from a mound reconnaissance dive (SD10). 

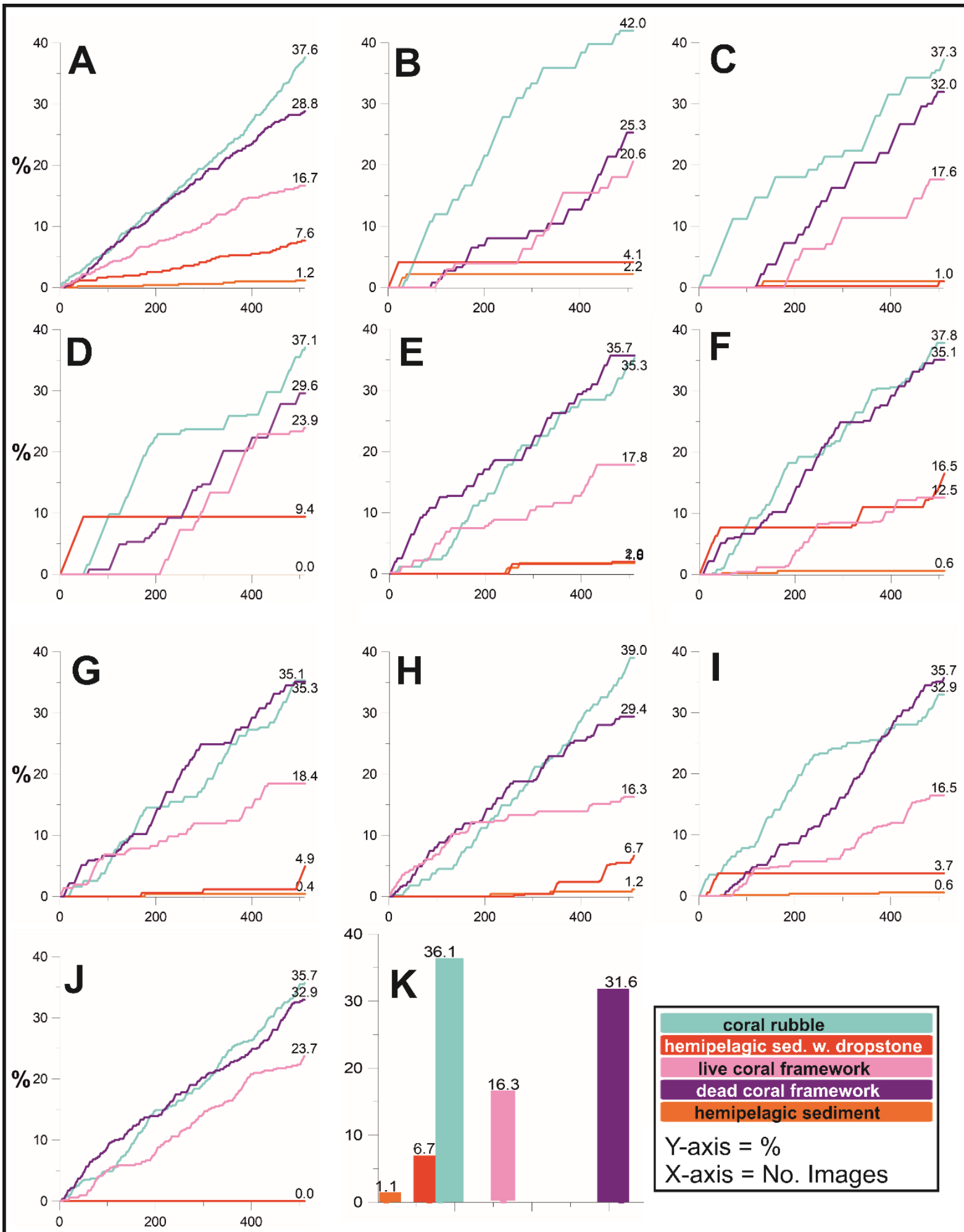

813 Figure 5 survey design results presented as facies sampling curves. A) random points (SD1), 814 B) south-north transect (SD2),C) east-west transect (SD3), D) northwest-southeast diagonal 815 transect (SD4), E) 2 lines (SD5), F) 3 straight, parallel line grid (SD6), G) 3 summit-crossing 816 lines (SD7), H) horizontal grid (SD8), I) spiral (SD9), J) an actual survey transect from a 817 mound reconnaissance dive (SD10) and K) single axis bar chart showing the total proportion of observed facies across the Piddington Mound. A) to J) $y$-axis $=\%$ percentage of facies, $x$ axis $=$ number of images, $K$ ) $y$-axis $=\%$ 


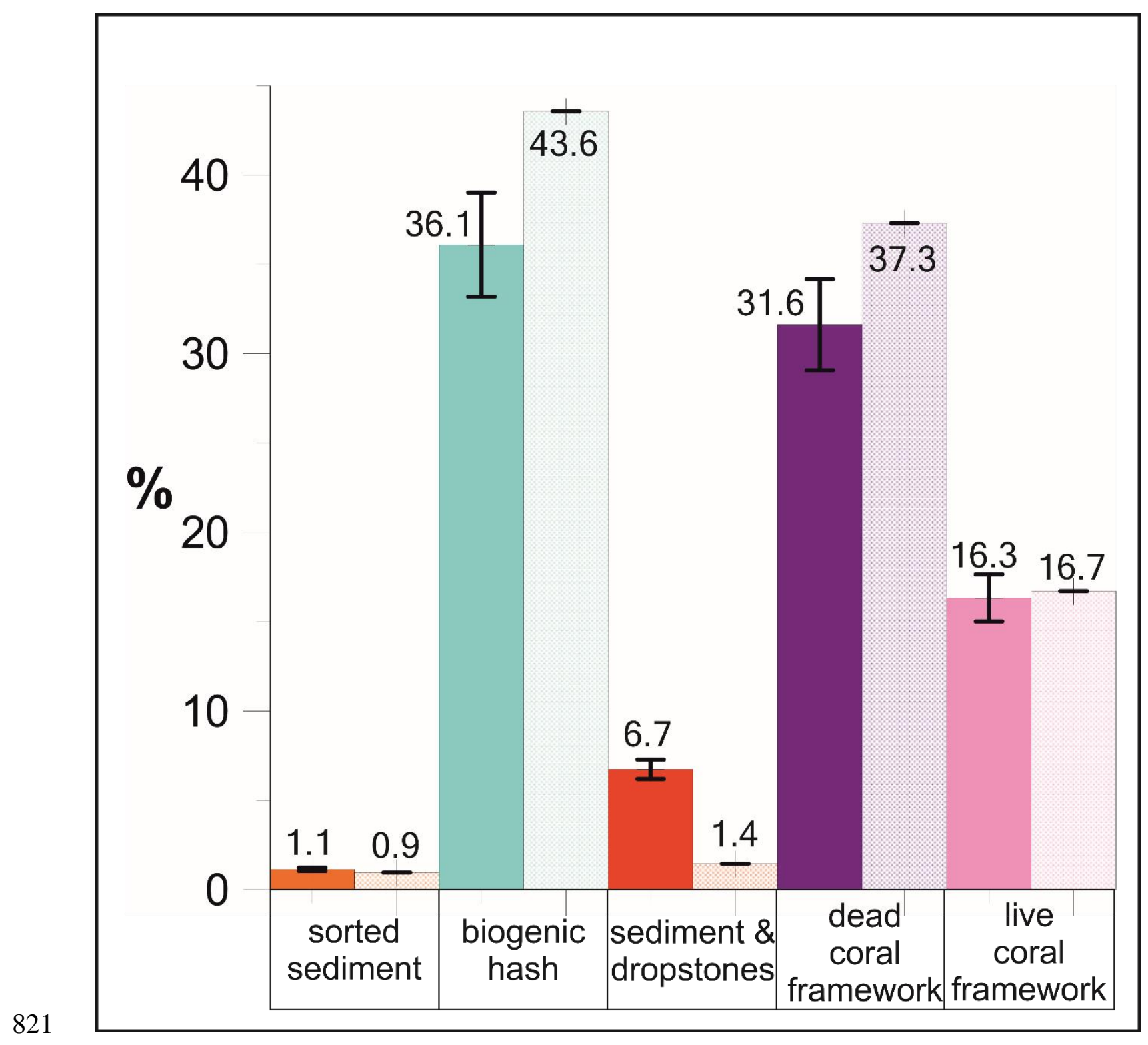

Figure 6 Graph comparing T1 and T4 facies.

823 T1 Piddington Mound cell-type proportions in checker fill. T4 Piddington Mound cell-type 824 proportions in solid fill. 


\begin{tabular}{|c|c|c|c|}
\hline alpha $(\boldsymbol{\alpha})$ & $\left(\mathbf{d}^{\mathbf{2}} \mathbf{n}\right)$ & $\mathbf{m}$ & $\boldsymbol{x}=(\mathbf{n}$ if $\mathbf{d}=\mathbf{0 . 0 5})$ \\
\hline 0.5 & 0.44129 & 4 & 177 \\
\hline 0.4 & 0.50729 & 4 & 203 \\
\hline 0.3 & 0.60123 & 3 & 241 \\
\hline 0.2 & 0.74739 & 3 & 299 \\
\hline 0.1 & 1.00635 & 3 & 403 \\
\hline 0.05 & 1.27359 & 3 & 510 \\
\hline 0.025 & 1.55963 & 2 & 624 \\
\hline 0.02 & 1.65872 & 2 & 664 \\
\hline 0.01 & 1.96986 & 2 & 788 \\
\hline 0.005 & 2.28514 & 2 & 915 \\
\hline 0.001 & 3.02892 & 2 & 1212 \\
\hline 0.0005 & 3.3353 & 2 & 1342 \\
\hline 0.0001 & 4.11209 & 2 & 1645 \\
\hline
\end{tabular}

829 Alpha values $(\alpha)$ represents the significance level which can be used to calculate the confidence 830 level (e.g. an alpha of 0.05 gives a confidence level of 95\%), $d$ is the margin of error, $n$ is the 831 sample size, $m$ is the minimum number of categories required (see Thompson (1987) for further 832 details on $m$ ), $X$ is sample size. 


\begin{tabular}{|l|l|l|}
\hline Class & Description & Typical Environment \\
\hline semipelagic & $\begin{array}{l}\text { cell dominated ( }>90 \% \text { cell } \\
\text { coverage) by hemipelagic sediment } \\
\text { i.e. sand or mud with no } \\
\text { recognisable bioclasts or } \\
\text { dropstones }\end{array}$ & $\begin{array}{l}\text { no dropstones nor deposition of } \\
\text { biogenic material. Potentially } \\
\text { deposition of a sorted sediment } \\
\text { under the influence of benthic } \\
\text { currents. }\end{array}$ \\
\hline coral rubble & $\begin{array}{l}\text { cell dominated ( }>50 \% \text { cell } \\
\text { coverage) by recognisable biogenic } \\
\text { material (i.e. coral rubble, shell } \\
\text { fragments) and sediment }\end{array}$ & deposition of mound-derived material \\
\hline $\begin{array}{l}\text { hemipelagic } \\
\text { sediment with } \\
\text { dropstones }\end{array}$ & $\begin{array}{l}\text { cell dominated ( }>50 \% \text { cell } \\
\text { coverage) by dropstones and } \\
\text { sediment (sand or mud) }\end{array}$ & $\begin{array}{l}\text { erosion, non-deposition or non-coral } \\
\text { growth since the deposition of the } \\
\text { dropstones }\end{array}$ \\
\hline $\begin{array}{l}\text { dead coral } \\
\text { framework }\end{array}$ & $\begin{array}{l}\text { cell dominated }(>50 \% \text { cell } \\
\text { coverage) by coral framework } \\
\text { which has no identifiable living } \\
\text { parts }\end{array}$ & coral no longer grows \\
\hline $\begin{array}{l}\text { live coral } \\
\text { framework }\end{array}$ & $\begin{array}{l}\text { cell dominated ( }>50 \% \text { cell } \\
\text { coverage) by coral framework with } \\
\text { identifiable living parts }\end{array}$ & \\
\hline
\end{tabular}

\begin{tabular}{|l|r|r|r|}
\hline Class & \multicolumn{1}{|l|}{ T1_\% } & \multicolumn{1}{l|}{ T4_\% } & \multicolumn{1}{l|}{ \% } \\
\hline hemipelagic sediment & $1.14( \pm 0.09)$ & 0.96 & -0.18 \\
\hline coral rubble & $36.1( \pm 3.14)$ & 43.57 & 7.47 \\
\hline hemipelagic sediment with dropstones & $6.74( \pm 0.58)$ & 1.45 & -5.29 \\
\hline dead coral framework & $31.61( \pm 2.75)$ & 37.3 & 5.69 \\
\hline live coral framework & $16.38( \pm 1.42)$ & 16.72 & 0.34 \\
\hline no data & 8 & 0 & \\
\hline Sum of classified cells & 100.0 & 100.0 & \\
\hline
\end{tabular}
Piddington Mound proportions (T4_\%).

839 The $\Delta$ \% column represents the percentage change between $T 1$ and T4. All values are rounded 840 up to the nearest two decimal places. Error margins are proportionally distributed from "no 841 data" values. 